\title{
Mining for Restriction Endonucleases in Nicaragua
}

\author{
Suyén S. Espinoza-Miranda*, Julio A. Gómez-Rodríguez** and Jorge A. \\ Huete-Pérez **
}

\section{Recibido: octubre/ Aceptado: noviembre 2012}

The Molecular Biology Center at the University of Central America in Nicaragua (CBM-UCA) was founded in 1999 to strengthen biotechnology research capacity and education in Nicaragua and the Central American region. One of the first projects launched by the CBM-UCA was bio-prospecting for key industrial enzymes. This ongoing study seeks to discover and characterize restriction enzymes (RE) in bacteria, and to create a database of microorganisms isolated and identified by $16 \mathrm{~S}$ rDNA sequencing methodology. In this paper we highlight the importance of studying the extreme environmental conditions for building knowledge of Nicaraguan biodiversity through modern molecular biology techniques such as metagenomics. The isolation of prototype enzymes such as EcoRV and ClaI is presented as an update and extension of previously undertaken work.

Keywords: bioprospecting, database, endonucleases, restriction enzyme

\section{Introduction}

Nicaragua is located on the Central American isthmus and acts as a bridge for biodiversity exchanges between North and South America. According to the Ministry

\footnotetext{
*Molecular Biology Center, University of Central America, Nicaragua

Email: suyenespinoza@uca-cbm.org

** Molecular Biology Center, University of Central America, Nicaragua

***Dr. Jorge A. Huete-Perez is director of the Molecular Biology Center at UCA and a research scientist at Ocean Genome Legacy, MA., USA. Correo electronic: jorgehuete@uca-cbm.org
} 
of Environment and Natural Resources of Nicaragua (MARENA, 2010), the country is host to $7 \%$ of the world's biodiversity. Because of its geographical position and the geology of its terrain, Nicaragua encompasses many different ecosystems abounding with unexplored biodiversity awaiting future discovery.

The Molecular Biology Center at Nicaragua's University of Central America (CBM-UCA) is committed to strengthening science research and education in the region. In 1999, the CBM began building scientific capacity in Nicaragua by initiating a project of bio-prospecting for enzymes of industrial importance. Bioprospection is the exploration of biodiversity for commercially valuable genetic and biochemical resources, as defined in The Convention on Biological Diversity (CBD). Bioprospecting has existed since the first humans determined that certain plants were useful for specific purposes. Currently, new bioprospecting activities are focusing on organisms that thrive at high temperatures known as extreme thermophiles. These thermophiles are hosts to a variety of enzymes of much importance to the field of molecular biology. For example, the Taq polymerase enzyme, identified in Escherichia coli samples found in hot springs in 1969, is often used in Polymerase Chain Reaction (PCR) procedures, a technique which produces mass quantities of selected DNA fragments. Another result of bioprospecting was the discovery of the Pfu polymerase, an example of an extreme thermophile identified in 1986 in Pyrococcus furiosus, a microorganism of the Archaea domain living in thermal marine sediments in Italy. The Pfu polymerase is now often preferred for PCR because of its low error rate during replication.

The main objective of previous bio-prospecting efforts in Nicaragua was to search for restriction enzymes (RE) in bacteria in Nicaraguan soils (Gomez-Rodriguez, J. A., \& Huete-Perez, J. A., 2008). Restriction enzymes, also known as restriction endonucleases, are among the most often used enzymes in molecular biology. Their importance lies in their ability to manipulate DNA by binding to and cleaving specific segments of DNA. After many years of carrying out bioprospecting for potentially useful RE, the CBM-UCA is now creating a library of microorganisms isolated in Nicaragua that contain RE activities. This database will provide the materials for more in-depth research in the future.

\subsection{Restriction Enzymes Timeline.}

The discovery in 1953 of the double helical structure of the DNA molecule by James Watson and Francis Crick set the stage for a new era in molecular biology and opened the door to extensive research of the "hereditary molecule". Part of this research was focused on the study of genomes, but scientists were hampered by their inability to separate DNA molecules into small fragments to study its properties. These new studies were also dependant on the discovery and use of enzymes capable of modifying existing DNA molecules, or to assist in the synthesis of new DNA molecules. In 1956, Dr. Arthur Kornberg isolated the first DNA polymerizing enzyme, and in 1967, Drs. C. C. Richardson and B. Weiss published their paper on their isolation of DNA ligase (Weiss, B. \& Richardson, C. C., 1967).

Along with these studies, experiments with bacteria were generating new sources of possible discoveries that were to have a major impact on the field of 
molecular biology. In the early 50 's, Dr. Salvador E. Luria and collaborators proposed a mechanism to account for the phenomenon of variable growth of bacteriophages in different host strains of bacteria (host-controlled restriction modification). Further studies on Escherichia coli postulated a restriction and modification model in which bacterial cells would contain two types of enzymes. One type would recognize a specific fragment of DNA and the other would function as a modification enzyme. This molecular model to explain host-controlled modification was presented by W. Arber and D. Dussoix (1962).

In 1970 Smith and colleagues described the purification of a type II RE, HindII, but also the characterization of its recognition and cleavage site (Smith \& Welcox, 1970). Eight years later, Werner Arber, Hamilton O. Smith and Daniel Nathans were awarded the Nobel Prize for Medicine and Physiology in recognition of the discovery of RE and their relevance to the development of molecular genetics. Another key study in the area of restriction endonucleases was published in 1976 by Dr. Richard J. Roberts. Dr. Roberts' study covered properties and characteristics of restriction enzymes, and also suggested possible uses of RE (Roberts, 1976).

Restriction endonucleases became a popular tool in the 80 's because they allowed DNA typing with applications in forensic genetics, human identification and diagnoses of inherited diseases. An example of a molecular biology technique that involves RE is RFLP (Restriction Fragment Length Polymorphisms). In 1980, D. Botstein and colleagues published a study in which they used RE to diagnose inherited diseases. RFLP were obtained by using restriction endonucleases to generate a number of segments that divided the DNA. These RFLP were used as the genetic markers which fostered the study of the entire human genome (Botstein et al., 1980).

\subsection{Types, uses and applications of restriction enzymes.}

There are four types of RE, characterized as follows:

Type I RE were first isolated from E. coli. These enzymes are complex and are able to cut DNA strands at random distances from their recognition sites. These restriction and modification enzymes are dependent upon Adenosine TriPhosphate (ATP), magnesium ions $\left(\mathrm{Mg}^{2+}\right)$ and S-Adenosyl methionine (AdoMet) to carry out their activities. According to New England Biolabs, the first commercial provider of restriction enzymes, Type I RE are limited to random cuts at more than 1000 base pairs (bp).

Type II RE are the best known and most widely used in the laboratory. They cut DNA at specific recognition sequences producing restriction fragments useful for gene cloning. They require $\mathrm{Mg}^{2+}$ ions for catalyst and are comprised of different subtypes. For example, Type IIS recognizes asymmetric sequences. Type IIF interacts with two copies of their recognition sequences; Type IIE is similar but one copy acts as a cleavage and the other serves as the allosteric effector. Type IIB is a restriction and modification enzyme and can recognize symmetric and asymmetric sequences. Type IIG is similar to IIB however modification and restriction activities are present in just one strand of the DNA. Type IIT RE are heterodimers and aid in the recognition of palindromic sequences (Pingoud \& Jeltsch, 2001). 
Type III restriction endonucleases are also restriction and modification enzymes. They cut DNA at around $20 \mathrm{bp}$ after the recognition site and require two similar sequences in opposite orientations within the same DNA molecule to undergo cleavage (Aelst et al., 2010).

The following table explains the main applications of RE and their significance to the world of molecular genetics.

Table 1. Uses of RE in molecular genetics techniques

\begin{tabular}{|l|l|}
\hline \multicolumn{1}{|c|}{ Technique } & \multicolumn{1}{|c|}{ Applications } \\
\hline $\begin{array}{l}\text { RFLP } \begin{array}{c}\text { Fragment } \\
\text { Polymorphisms) }\end{array} \\
\text { Length }\end{array}$ & $\begin{array}{l}\text { First typing DNA method used in human identity } \\
\text { tests (Budowle et al., 2000). Widely used in forensic } \\
\text { genetics as markers for genetic linkage analysis, } \\
\text { population genetic studies and hereditary diseases } \\
\text { (Watson et al., 1992:519-535). }\end{array}$ \\
\hline $\begin{array}{l}\text { AFLP (Amplified Fragment } \\
\text { Length Polymorphisms) }\end{array}$ & $\begin{array}{l}\text { Combines the use of RE and polymerase chain } \\
\text { reaction (PCR) (Geornaras et al., 1999). Has been } \\
\text { applied to the studies of genetic variations in natural } \\
\text { population of Pinus oocarpa from Nicaragua using } \\
\text { two REs Msel and PstI) (Día et al., 2001). }\end{array}$ \\
\hline $\begin{array}{l}\text { PFGE (Pulsed Field Gel } \\
\text { Electrophoresis): }\end{array}$ & $\begin{array}{l}\text { Gold standard technique used in molecular } \\
\text { identification of chromosomal DNA. Used to } \\
\text { separate fragments from 10 to 800kb. Data is } \\
\text { analyzed with software. Drawback is that results } \\
\text { are obtained in two to three days limiting the } \\
\text { examination of a large quantity of samples (Olive \& } \\
\text { Bean, 1999). }\end{array}$ \\
\hline $\begin{array}{l}\text { RSM assay (Restriction Site } \\
\text { Mutation Assay) }\end{array}$ & $\begin{array}{l}\text { Technique used for the study of mutations in codons } \\
\text { that are key genes related to the development of } \\
\text { tumors (Jenkins et al., 2002). }\end{array}$ \\
\hline $\begin{array}{l}\text { PCR/REA (Polymerase } \\
\text { Chain } \\
\text { Restriction } \\
\text { Enzyme Analysis): }\end{array}$ & $\begin{array}{l}\text { This method is based on the amplification of a } \\
\text { variable region of the 23S rRNA followed by the } \\
\text { digestion of two restriction enzymes. According to } \\
\text { Engvall et al. (2002), this method is easy to perform } \\
\text { and allows the identification and differentiation of } \\
\text { closely related bacterial species. }\end{array}$ \\
\hline
\end{tabular}

Modified from: Gomez-Rodriguez, J. A., \& Huete-Perez, J. A., 2008.

\section{Materials and methods}

Since 1999 the Molecular Biology Center at the University of Central America (CBM-UCA) has been involved in bio-prospecting for key industrial enzymes, including restriction enzymes. This ongoing study seeks to discover and identify restriction enzymes from bacteria, and to create a database of microorganisms isolated 
and identified by $16 \mathrm{~S}$ rDNA sequencing methodology. Here we highlight the main methodology employed. In this research we have been working in collaboration with New England Biolabs, Inc., USA.

\subsection{Reagents, enzymes and DNA substrates}

All chemical reagents were purchased from SIGMA-Aldrich and Fischer Scientific (Fair Lawn, NJ, USA). RE and their respective buffers were obtained from New England Biolabs (Beverly, MA, USA). Purification pump and column chromatography were from General Electric (Township, MI). The methodology used was an adaptation of previous protocols published in Gomez-Rodriguez, J. A., \& Huete-Perez, J. A., 2008.

\subsection{Isolation of microorganisms and culture conditions}

Bacteria were isolated from soil samples taken from different regions of Nicaragua including forests and volcanic soil (Cerro Negro, San Jacinto thermal waters and Teotecacinte) with a temperature range of $37-68^{\circ} \mathrm{C}$. The medium used for growing bacteria was LB agar Miller (10g of tryptone, $5 \mathrm{~g}$ of yeast extract, and $10 \mathrm{~g}$ of $\mathrm{NaCl}$ per every $500 \mathrm{ml}$ prepared) and Select Agar as solidifying agent. In addition, $5 \mathrm{ml}$ of soil were added to the mixture of LB agar to increase the diversity of the colonies. The medium was sterilized using an autoclave. Duplicates of the plates were made to incubate at $37^{\circ} \mathrm{C}$ and $65^{\circ} \mathrm{C}$ to maximize the spreading of mesophile and thermophile bacteria. After 18 hours of incubation, colonies were selected and isolated to new and sterile LB agar plates.

Cell disruption was done by adding $1.5 \mathrm{ml}$ of lysis buffer (Tris- $\mathrm{HCl} 20 \mathrm{mM}$, EDTA $0.5 \mathrm{mM}, \mathrm{NaCl} 50 \mathrm{mM}$, DTT $1 \mathrm{mM}, \mathrm{pH} 7.5)$ and $15 \mu \mathrm{l}$ of phenylmethylsulfonyl fluoride(PMSF) was added as a serine protease inhibitor at a concentration of $6 \mathrm{mg} /$ $\mathrm{ml}$. Cells were lysed by sonication intermittently on ice for 30 seconds at 4 watts $/ \mathrm{sec}$. Cell debris was removed by centrifugation at 14,000 rpm for $6 \mathrm{~min}$. The supernatant was transferred to a new sterile eppendorf tube. The enzyme crude was stored at $4{ }^{\circ} \mathrm{C}$ until use.

\subsection{Restriction enzyme assays}

Screening of the different isolates for RE was performed with either crude lysate or the purified enzyme using pUC19, PhiX 174, pBR322 and Lambda $(\lambda)$ DNA. One $\mu \mathrm{l}$ of plasmid completed the digestion in $1 \mathrm{~h}$ at the corresponding temperature in 60 $\mu \mathrm{l}$ of reaction mixture. Once the enzyme activity was confirmed by electrophoresis, another assay was done to test the proper buffer in which the enzyme worked the best. Restriction mapping was done to determine the possible restriction point of the unknown enzyme.

\subsection{Purification}

The enzyme crude was purified using an ion-exchange column chromatography method. An heparin matrix column (Hi Trap Hp, Amersham Biosciences) and a 
protein purification pump were used (Pharmacia, model LKB-Pump 1) at a flow rate of $2 \mathrm{ml} / \mathrm{min}$. Proteins were eluted with a $\mathrm{NaCl}$ gradient from $50 \mathrm{mM}$ buffer (Tris- $\mathrm{HCl}$ $20 \mathrm{mM}$, EDTA $0.5 \mathrm{mM}, \mathrm{NaCl} 50 \mathrm{mM}$, DTT $1 \mathrm{mM}$, BME $10 \mathrm{mM}, 5 \%$ glycerol) to $1 \mathrm{M}$ buffer (Tris-HCl 20mM, EDTA 0.5mM, NaCl 1M, DTT 1mM, BME 10mM, 5\% glycerol). Around 20 fractions were collected and electrophoresed to elute the enzyme from the column.

16S $r$ DNA sequencing and analysis. DNA was isolated using the Wizard Genomic DNA purification kit (Promega, Madison, WI, USA) and colony PCR method by taking bacterial cells directly from the plate or stored colonies at $-20{ }^{\circ} \mathrm{C}$. A region of approximately $1500 \mathrm{bp}$ from the $16 \mathrm{~S}$ rRNA gene was amplified using universal primers: fD1 (AGAGTTTGATCCTGGCTCAG) and rP1 (ACGGTTACCTTGTTACGACTT) (Weisburg et al., 1991) Phusion HF PCR master mix (NEB, Beverly, MA, USA) was used. The PCR program consisted of an initial denaturation step of 2 min at $98{ }^{\circ} \mathrm{C}$ followed by 35 cycles of $15 \mathrm{sec}$ at $98{ }^{\circ} \mathrm{C}, 15 \mathrm{sec}$ at $65^{\circ} \mathrm{C}, 30 \mathrm{sec}$ at $72{ }^{\circ} \mathrm{C}$ and a final extension step of $2 \mathrm{~min}$ at $72{ }^{\circ} \mathrm{C}$. A previously isolated Geobacillus bacterium from Nicaragua was used as a positive control in the PCR assays and template DNA was omitted from the reaction mixture for the negative control. For visualizing PCR products, $7 \mu \mathrm{L}$ of the reaction mix was electrophoresed on $1 \%$ agarose gels in $1 \mathrm{X}$ TAE buffer, which were then stained with ethidium bromide and examined under UV light. DNA was sequenced using BigDye Terminator v3.1 Cycle Sequencing Kit and ABI3130 Genetic analyzer (Life Technologies, Carlsbad, CA, USA) following manufacturer's recommendations. The $16 \mathrm{~S}$ rDNA nucleotide sequences of the 20 colonies were submitted to the Basic Local Alignment Search Tool (BLAST, http:// blast.ncbi.nlm.nih.gov/) to be compared with a database of known sequences and to determine the ones that are more similar to the query sequence.

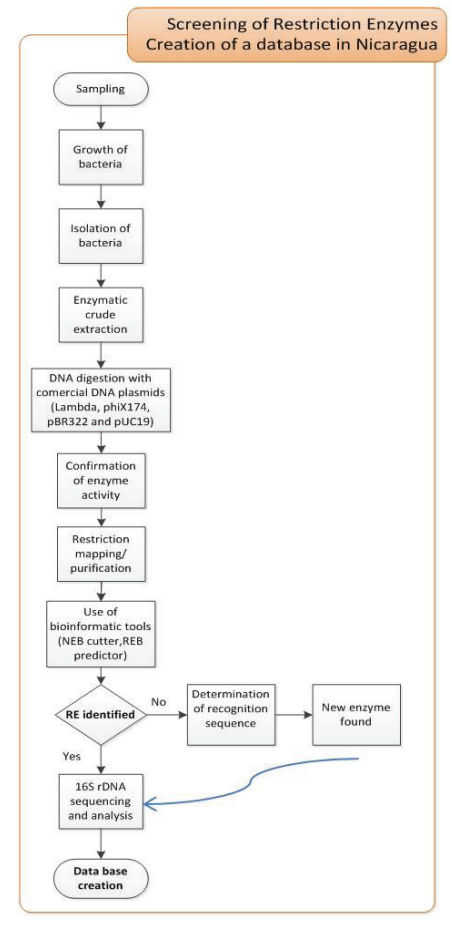

Figure 1. Searching for restriction enzymes in Nicaragua. This process has been adapted from Gomez-Rodriguez, J. A., \& Huete-Perez, J. A., 2008, including a step for the creation of a database. 


\section{Results and Discussion}

Over 50 different soil samples were analyzed in the period covered in this paper. Twenty-two enzyme activities have been recorded into a database. These restriction enzyme activities come from temperate as well as hot environments which illustrate the rich microbial diversity in Nicaraguan soils. For illustration purposes we selected two new enzyme activities found in 2012. These are prototypes EcoRV and ClaI, which were added to the collection of RE. Both enzymes were found in bacteria obtained from the same location but at different temperatures; EcoRV at $65^{\circ} \mathrm{C}$ and $\mathrm{ClaI}$ at $37^{\circ} \mathrm{C}$. Both samples underwent screening for restriction enzymes. Partial results which helped to determine restriction activity in Eco RV and ClaI are shown in Figures 2 and 3). One feature of this database is the inclusion of host bacterial information for each prototype enzyme. 16S rDNA sequencing and analysis was done to obtain the genetic information of the bacteria. The quality of the DNA amplicons was confirmed by PCR (see Figure 4).
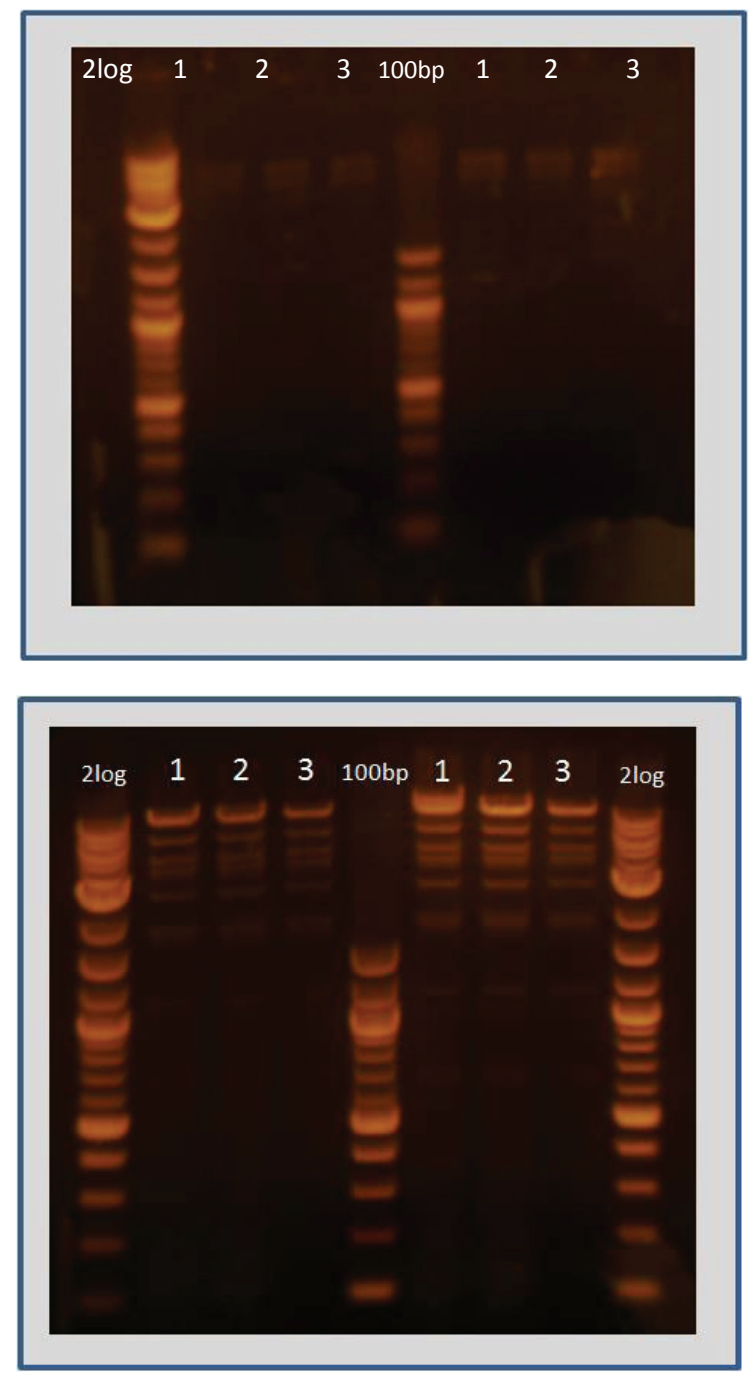

Figure 2. Double digestion reactions with crude extract UbaN 21(1) and EcoRV with Lambda DNA. 1. Crude, 2. Crude + EcoRV, 3. EcoRV. Both set of reactions were done in buffer 3. From this digestion it can be concluded that UbaN 21(I) crude is an isoschizomer of EcoRV

Figure 3. Double digestion reactions with crude extract UbaN 22(I) and ClaI on Lambda DNA. 1. Crude, 2. Crude +ClaI, 3. ClaI. The first three reactions were done in buffer 3 and the following three in buffer 4. From this digestion it can be concluded that UbaN 22(I) crude is an isoschizomer of ClaI. 
Figure 4. PCR products generated by the reaction of fD1 and rP1 pair of universal primers with microbial DNA. The positive control (+) was DNA from an isolated Geobacillus bacterium in Nicaragua. 1. UbaN 1(I), 2. UbaN 2(I), 3. UbaN 3(I), 4.

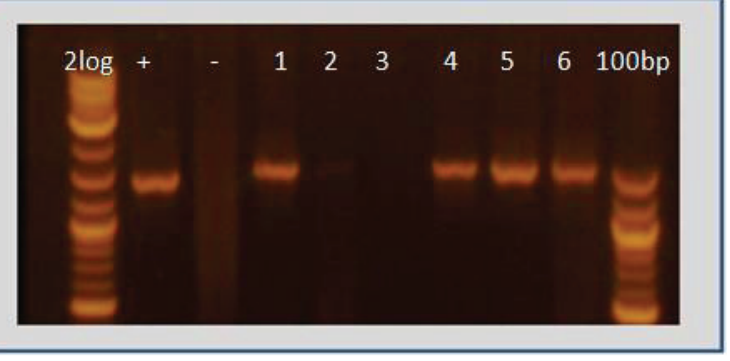

UbaN 4(I), 5. UbaN 5(I). Amplicons from 1, 4, 5 and 6 are suitable to do 16S rDNA analysis. Microbial DNA was taken straight from the stored colonies at $-20 \mathrm{oC}$. For UbaN 2(I) and UbaN 3(I) DNA was extracted and then amplified.

\subsection{Database of REs in Nicaragua}

The persistent identification of RE in bacteria from soils in Nicaragua reflects the variety of biodiversity in the country. The creation of an RE database by the CBM-UCA is a crucial step in advancing the development of bioprospection locally. The database not only includes the name of RE found and their location, but also the information of the microorganism containing this enzyme. This additional information on host microorganisms will aid in the future isolation of genes important to the study of RE cleavage sites. All the information regarding the enzymes has been entered into REBASE, the official database of restriction endonucleases. The following table shows the information stored in the RE database. The column entitled "source" lists the bacteria where the prototype enzyme can be found according to previously published information.

Table 2. Database showing RE prototype activities found in bacteria in Nicaragua.

\begin{tabular}{|c|c|c|c|c|}
\hline $\begin{array}{c}\text { REBASE } \\
\text { CODE }\end{array}$ & $\begin{array}{l}\text { Temp } \\
\left({ }^{\circ} \mathrm{C}\right)\end{array}$ & $\begin{array}{l}\text { *Enzyme } \\
\text { Prototype }\end{array}$ & ${ }^{* *}$ Source & BLAST Result \\
\hline UbaN 1(I) & 37 & Mbo I & Moraxella bovis & $\begin{array}{l}\text { B. niacini/B.drentensis/ B. } \\
\text { soli/ B.vireti/ B.bataviensis }\end{array}$ \\
\hline UbaN 2(I) & 37 & HaeIII & Haemophilus aegypticus & Not determined \\
\hline UbaN 3(I) & 37 & BamH I & $\begin{array}{l}\text { Bacillus } \\
\text { amyloliquefaciens }\end{array}$ & $\begin{array}{l}\text { Bacillus aerophilus/ Bacillus } \\
\text { stratosphericus }\end{array}$ \\
\hline UbaN 4(I) & 37 & EcoRV & E. coli & $\begin{array}{l}\text { B. aerophilus/B. } \\
\text { stratosphericus/ B. } \\
\text { altitudinis/ B. safensis }\end{array}$ \\
\hline UbaN 5(I) & 37 & Bfa I & Bacteroides fragilis & Sporosarcina Soli \\
\hline UbaN 6(I) & 55 & BsoB I & $\begin{array}{l}\text { Bacillus } \\
\text { stearothermophilus }\end{array}$ & $\begin{array}{l}\text { G. Vulcani / G. } \\
\text { thermoleovorans/ } \\
\text { G.stearothermophilus }\end{array}$ \\
\hline UbaN 6(II) & 55 & BsaBI & $\begin{array}{l}\text { Bacillus } \\
\text { stearothermophilus }\end{array}$ & $\begin{array}{l}\text { G. Vulcani / G. } \\
\text { thermoleovorans/ } \\
\text { G.stearothermophilus }\end{array}$ \\
\hline
\end{tabular}




\begin{tabular}{|c|c|c|c|c|}
\hline UbaN 7(I) & 37 & Ear I & Enterobacter aerogenes & $\begin{array}{l}\text { B. megaterium/B. flexus/ } \\
\text { B. asahii/ B.koreensis }\end{array}$ \\
\hline UbaN 8(I) & 37 & Hae III & Haemophilus aegypticus & $\begin{array}{l}\text { B. aerophilus/B. } \\
\text { stratosphericus/ } \\
\text { B.altitudinis/B. safensis }\end{array}$ \\
\hline UbaN 9(I) & 60 & Acl I & $\begin{array}{l}\text { Acinetobacter } \\
\text { calcoaceticus }\end{array}$ & $\begin{array}{l}\text { G.subterraneus } \\
\text { /G. vulcani/ G. } \\
\text { thermoleovorans/G. } \\
\text { thermodenitrificans/ } \\
\text { G.lituanicus }\end{array}$ \\
\hline UbaN 10(I) & 60 & BsaW I & $\begin{array}{l}\text { Bacillus } \\
\text { stearothermophilus }\end{array}$ & $\begin{array}{l}\text { Anoxybacillus gonensis/ } \\
\text { Anoxybacillus } \\
\text { kamchatkensis/ } \\
\text { Anoxybacillus ayderensis }\end{array}$ \\
\hline UbaN 11(I) & 60 & Nci I & Neisseria cinerea & $\begin{array}{l}\text { Anoxybacillus rupiensis/ G. } \\
\text { tepidamans/ Anoxybacillus } \\
\text { amylolyticus / G. } \\
\text { caldoxylosilyticus }\end{array}$ \\
\hline UbaN 11(II) & 60 & BstN I & $\begin{array}{l}\text { Bacillus } \\
\text { stearothermophilus }\end{array}$ & $\begin{array}{l}\text { Anoxybacillus rupiensis/ G. } \\
\text { tepidamans/Anoxybacillus } \\
\text { amylolyticus /G. } \\
\text { caldoxylosilyticus }\end{array}$ \\
\hline UbaN 12(I) & 60 & BssSI & $\begin{array}{l}\text { Bacillus } \\
\text { stearothermophilus }\end{array}$ & Not determined \\
\hline UbaN 13(I) & 60 & HpaII & $\begin{array}{l}\text { Haemophilus } \\
\text { parainfluenzae }\end{array}$ & Not determined \\
\hline UbaN 14(I) & 37 & BamH I & $\begin{array}{l}\text { Bacillus } \\
\text { amyloliquefaciens }\end{array}$ & $\begin{array}{l}\text { B.anthracis s. 14578/ } \\
\text { B.thuringiensis s.IAM/ } \\
\text { B. weihenstephanensis/B. } \\
\text { mycoides }\end{array}$ \\
\hline UbaN 15(I) & 67 & Ava II & Anabaena variabilis & Not determined \\
\hline UbaN 16(I) & 65 & BstN I & $\begin{array}{l}\text { Bacillus } \\
\text { stearothermophilus }\end{array}$ & $\begin{array}{l}\text { Raoultella ornithinolytica/ } \\
\text { Enterobacter aerogenes/ } \\
\text { Raoultella planticola/ } \\
\text { Enterobacter amnigenus }\end{array}$ \\
\hline UbaN 17(I) & 68 & Hind III & Haemophilus influenzae & $\begin{array}{l}\text { Geobacillus } \\
\text { vulcani/ Geobacillus } \\
\text { thermoleovorans/ } \\
\text { Geobacillus lituanicus/ } \\
\text { Geobacillus kaustophilus }\end{array}$ \\
\hline UbaN 18(I) & 65 & ClaI & Caryophanon latum & $\begin{array}{l}\text { G. vulcani/ G. } \\
\text { thermoleovorans/G. } \\
\text { lituanicus/ G. } \\
\text { hermocatenulatus }\end{array}$ \\
\hline
\end{tabular}




\begin{tabular}{|c|c|c|c|c|}
\hline UbaN 19(I) & 67 & $\mathrm{Xba} I$ & Xanthomonas badrii & $\begin{array}{l}\text { G. vulcani/ G. } \\
\text { thermoleovorans/ G. } \\
\text { lituanicus/ G. kaustophilus }\end{array}$ \\
\hline UbaN 20(I) & 65 & BsaB I & $\begin{array}{l}\text { Bacillus stearother- } \\
\text { mophilus B674 }\end{array}$ & $\begin{array}{l}\text { G. vulcani /G. } \\
\text { thermoleovorans/ G. } \\
\text { lituanicus/ G. kaustophilus }\end{array}$ \\
\hline UbaN 21(I) & 65 & EcoRV & E. coli & $\begin{array}{l}\text { G. caldoxylosilyticus/G. } \\
\text { toebii/Saccharococcus } \\
\text { thermophilus/G. } \\
\text { thermoglucosidasius }\end{array}$ \\
\hline UbaN 22(I) & 37 & ClaI & Caryophanon latum & $\begin{array}{l}\text { Lysinibacillus fusiformis/ } \\
\text { Lysinibacillus sphaericus } \\
\text { / Acetobacter } \\
\text { pasteurianus/ Lysinibacillus } \\
\text { parviboronicapiens }\end{array}$ \\
\hline
\end{tabular}

The information of the REBASE codes was taken from Gomez-Rodriguez, J. A., Eु Huete-Perez, J. A., 2008. *The enzyme prototype is the reference name given to the $R E$ activity after restriction mapping was done. **The source of each enzyme was taken from http://www.neb.com. This information can also be found in any literature that addresses the identification of any of the enzymes. The bacterial colonies are stored in glycerol at $-20^{\circ} \mathrm{C}$ at CBM-UCA. Notice that the last two prototypes enzymes have not been registered into REBASE.

Most of the BLAST results in the database presented in this paper belong to either the Bacillus or Geobacillus genus. At the end of the 70's, the Bacillus genus was consider to have played a major role in the development of microbial enzymes due to its heterogeneous group of species including mesophiles, thermophiles, neutrophiles, and others (Priest, 1977). Bacillus bacteria are found in every type of environment. In 1992, Wisotzjsey and colleagues did a comparative analysis in three bacillus species and proposed the creation of a new genus: "Alicyclobacillus gen. nov". According to Wisotzjsey, when doing a 16S rRNA analysis and comparison of the sequences in Bacillus species, they were too genetically different to fit on the same genus (Wisotzjsey et al., 1992).

Geobacillus is another predominant genus found in the RE database from Nicaragua. Geobacillus species can be isolated from a variety of environmental sources such as oil reservoirs, geothermal sources (Nazina et al., 2001), and temperate soil environments (Banat et al. 2004). According to Nazina et al., Geobacillus species are thermophilic with an optimal temperature range of $55-65^{\circ} \mathrm{C}$. The puzzle of this genus is that all the species have been characterized as thermophilic but they can be recovered from temperate environments (Marchant, 2011). This particular paradox can be used in further studies of the genus in Nicaragua as well as the different enzymes identified.

The bacterial source does not necessarily need to be the same as the one found in the BLAST results. Restriction enzymes might be present in different types of bacteria but with the same DNA recognition sequence. These enzymes are isoschizomers, restriction endonucleases that recognize the same target DNA sequence and that cleave it in the same way. For example, MboI (UbaN 1 (I)) is usually isolated from Moraxella bovis, but according to the BLAST result obtained in the database, the bacterial colony from where MboI was isolated in Nicaragua belongs to the Bacillus genus. This can be easily explained by looking at REBASE, 
where all the different isoschizomers of the RE can be found. BfuCI, Bsp143I, BssMI, BstKTI are isoschizomers of MboI. All of them are isolated from Bacillus species, as shown by the BLAST result. Likewise, Bfa I (UbaN 5 (I)) has three others isoschizomers: FspBI, MaeI, XspI, but none of them have been determined to be found in Sporosarcina soli. Further research showed that Sporosarcina soli belongs to the Bacillaceae family (Soon-Wo, et al., 2007) home of the Bacillus genera.

For BstNI (UbaN 16 (I)), there is a variety of isoschizomers from a host of bacteria: AjnI, BseBI, BstOI, Bst2UI, EcoRII, MvaI, Psp6I, PspGI. However, the first hits for the query sequence shown in BLAST are from Raoultella and Enterobacter genus, completely different from the expected result for the known RE and its isoschizomers. This new discovery of an enzyme prototype from BstNI in a genus such as Enterobacter might be of interest due to its pathogenic history in humans. Lysinibacillus sphaericus, host of the ClaI prototype is used as an insecticide. Their spores release an endotoxin that kills mosquito larvae. It is an ideal biological control to manage mosquito populations that are vectors for diseases such as malaria and dengue which remain difficult to control in tropical developing countries (Wirth et al., 2007).

\subsection{Metagenomics and bioinformatics for RE detection in Nicaragua}

Until now, the CBM-UCA has been using a traditional microbiology method for detection of restriction enzymes in bacteria, but because of the slow rate of screening, it has limited the possibility of new discoveries. Innovative technologies which allow massive DNA sequencing are now encompassing new methodologies such as metagenomics (Oremland et al., 2005). Metagenomics facilitates the investigation and screening of DNA from microorganisms which have not been cultured in the lab. Metagenomics is a very powerful means that can be employed to analyze microbial communities in spite of the difficulties to culture individual bacteria or microorganisms in the laboratory. In metagenomics it is possible to analyze the genomes of microbial DNA that is extracted directly from communities present in environmental samples, including soil, water or other sources.

The incorporation of genomic and metagenomic techniques at the CBMUCA will add value to regional biodiversity studies and offer potentially useful products as biocatalysts and drug molecules of high demand for bioindustry. It would usher Nicaragua into the post-genomic era and facilitate the study of genomes using computational biology techniques. In the case of restriction endonucleases, DNA can be isolated from environmental samples and specific genes which act as a foundation for methylases associated with the RE bacterial host (RM systems) can be amplified. Using bioinformatic tools methylases are found within the complete genomes of already sequenced bacteria and from there on the partner restriction enzymes can be easily isolated.

One consideration to take into account when doing metagenomics of soil sampling, is the intricacy of extracting environmental DNA. Soil metagenomes are complex due to the presence of thousands of different species. On the other hand microorganisms growing under extreme temperatures are limited in their biodiversity and complexity (Wolfgang \& Rolf, 2010). 




Figure 5. Diagram of a general approach to metagenomic research.

\subsection{The importance of exploring volcanic environments through molecular biology research}

Nicaragua is part of the volcanic range of Central America. With 13 active volcanoes, Nicaragua has become a target of study for many researchers in the microbial biodiversity area. A good example of this interest is the biodiversity assessment of Nicaragua's volcanic environments. Using the Nicaraguan Cerro Negro volcano as a reference environment, fundamental questions regarding the origin of life on Earth can be explored, as they are being explored on planet Mars (Hynek et al, 2008).

According to a geomicrobial analysis done in the Cerro Negro volcano, there are uniquely geothermal environments similar to Solfatara, Italy, which are expected to host unique microbial communities (Hynek et al., 2011). According to Hynek et al., Cerro Negro, Nicaragua, makes an "excellent terrestrial analog for acidsulfate weathering of Mars-like basalts", because acidic sulfur-bearing gases interact with recently erupted basaltic ash in numerous active fumaroles. The capacity of thermophilic microorganisms - in spite of varying environmental conditions - to make it in extremely hot environments lies in the special enzyme proteins (extremozymes) designed to work in exceedingly high temperatures. It will be possible to amplify, sequence and record all genomes present in natural environments such as these and to build an inventory of the ecosystems' genomics. Also, as thermophiles become gradually more important in biotechnological research, the increasing number of research groups and bioprospecting activities may represent a good opportunity for Nicaragua in terms of scientific discoveries and for profiting research results as well.

\section{Acknowledgement}

Research work at the Molecular Biology Center, University of Central America, is funded with CBM's research funds and through collaborative support of New England Biolabs, Inc., USA. 


\section{References}

Aelst , K. V., Toth, J., Ramanathan, S. P., Schwarz, F. W., Seidel , R., \& Szczelkun, M. D. (2010). Type III restriction enzymes cleave DNA by long-range interaction between sites in both head-to-head and tail-to-tail inverted repeat. (N. N. Laboratory of Molecular Biology, Ed.) Proceedings of the National Academy of Sciences (PNAS), 107 (20). Retrieved from http://www.ncbi.nlm.nih.gov/pmc/articles/ PMC2889075/ in October 10,2012.

Arber, W., \& Dussoix, D. (1962). Host Specificity of DNA Produced by Escherichia Coli.I. Host Controlled modification of bacteriophage lambda. Journal of Molecular Biology. Retrieved from http://www.ncbi.nlm.nih.gov/pmc/articles/PMC1210762/ in October 6,2012

Banat I, Marchant R, Rahman T (2004) Geobacillus debilis sp. nov., a novel obligately thermophilic bacterium isolated from a cool soil environment and reassignment of Bacillus pallidus to Geobacillus pallidus comb. nov. Int J Syst Evol Microbiol 54. Retrieved from http://www.ncbi.nlm.nih.gov/pubmed/15545458 in October 8,2012

Cailleau B, . (2007). Stress accumulation between volcanoes: an explanation for intraarc. Geophysical Journal International , 1-7.

Botstein, D., White. R., \& Skolnick, M. (1980). Construction of a Genetic Linkage Map in Man Using Restriction Fragment Length Polymorphisms. American Society of Human Genetics., 32. Retrieved from http://www.ncbi.nlm.nih.gov/ pmc/articles/PMC1686077/ in September 28,2012

Gómez-Rodriguez, J. A., \& Huete-Perez, J. A. (2008). Bioprospección de enzimas de restricción en bacterias de suelos y ambientes volcánicos de Nicaragua. Encuentro (81), 70-87.

Hynek, B. M., McCollom, T. M., \& Rogers, K. L. (2011). Cerro Negro volcano, Nicaragua: An assessment of geological and potential biological system on early Mars. In B. W. Garry, J. E. Bleacher, \& T. G. America (Ed.), Analogs for Planetary Exploration (pp. 279-285).

Jeltsch, A. (2002). Beyond Watson and Crick: DNA Methylation and Molecular Enzymology of DNA Methyltransferases. ChemBioChem , 3, 274- 293. Retrieved from http://onlinelibrary.wiley.com/doi/10.1002/1439-7633 \%2820020402\%293: $\quad 4 \% 3 C 274:: A I D-C B I C 274 \% 3 E 3.0 . C O ; 2-S /$ full in September 30, 2012

Marchant, I. M. (2011). Geobacillus Activities in Soil and Oil Contamination Remediation. In I. a. Banat, N. A. Logan, \& P. De Vos (Eds.), Endospore-forming Soil Bacteria (Vol. 27, pp. 259-270). New York: Springer.

MARENA. (2010). Biodiversidad: Revista Nicaraguense. Nicaragua.

Morgan R. (2012) Finding restriction endonucleases from environmental DNAs. VI Nicaraguan Biotechnology Meeting, 2012

Nazina TN, et al., (2001). Taxonomic study of aerobic thermophilic bacilli: descriptions of Geobacillus subterraneus gen. nov., sp. nov. and Geoba- cillus uzenensis sp. nov. from petroleum reservoirs and transfer of Bacillus stearothermophilus, Bacillus thermocatenulatus, Bacillus thermoleovorans, Bacillus kaustophilus, Bacillus ther- moglucosidasius and Bacillus thermodenitrificans to Geobacillus as the new combinations G. stearothermophilus, G. thermocatenulatus, 
G. thermoleovorans, G. kaustophilus, G. thermoglucosidasius and G. thermodenitrificans. InternationalJournalofSystematicand EvolutionaryMicrobiology, 51. Retrieved from http://www.ncbi.nlm.nih.gov/pubmed/11321089 in October 5, 2012

Oremland, R. S., Capone, D. G., Stolz, J. F., \& Fuhrman, J. (2005). Whither or wither geomicrobiology in the eraof 'community metagenomics'. Nature Reviews, 3. Retrieved from http://www.ncbi.nlm.nih.gov/pubmed/15953928 in October 2,2012

Pingoud, A., \& Jeltsch, A. (2001). Structure and function of type II restriction endonucleases. Nucleic Acids Research, 29 (18). Retrieved from http://nar.oxfordjournals.org/ content/29/18/3705 in October 13, 2012

Physiology or Medicine 1978 - Press Release". Nobelprize.org. 10 Nov 2012 http:// www.nobelprize.org/nobel_prizes/medicine/laureates/1978/press.html

Priest, F. (1977). Extracellular Enzyme Synthesis in the Genus Bacillus. Bacteriological Reviews, 41 (3), 711-753. Retrived from http://www.ncbi.nlm.nih.gov/ pmc/ articles/PMC414021/in November 1, 2012

Roberts, R. J. (1976). Restriction Endonucleases. Critical Reviews in Biochemistry , 123 164. doi: 10.1101/087969426.25.35.

Rogers, K. L., Hynek, B. M., \& McCollom, T. M. (2011). Photosynthesis within Mars' volcanic craters?: Insights from Cerro Negro Volcano, Nicaragua. Retrieved from http://adsabs.harvard.edu/abs/2011AGUFM.P33B1768R in November 1, 2012

Smith, H. O., \& Welcox, K. W. (1970). A restriction enzyme from Hemophilus influenzae. I. Purification and general properties. Journal of Molecular Biology, 51 (2), 379-391. Retrieved from http://202.114.65.51/fzjx/wsw/newindex/wswfzjs/pdf/27 in November 2,2012

Soon-Wo, K., Byung-Yong, K., Jaekyeong, S., Hang-Yeon, W., Peter, S., Brian J., T. (2007). Sporosarcina koreensis sp. nov. and Sporosarcina soli sp. nov., isolated from soil in Korea. International Journal of Systematic and Evolutionary Microbiology , 1694-1698. Retrieved from http://ijs.sgmjournals.org/content/57/8/ 1694. full in October 27, 2012.

Weisburg, W. G., Barns, S. M., \& Pell, D. A. (1991). 16S Ribosomal DNA Amplification for Phylogenetic Study. Journal of Bacteriology, 173 (2), 697-703. Retrieved from http://jb.asm.org/content/173/2/697.full.pdf + html in October 5,2012

Wirth, M. C., Yang, Y., Walton, W. E., Federici, B. A., \& Berry, C. (2007). Mtx Toxins Synergize Bacillus sphaericus and Cry11Aa against Susceptible and Insecticide-Resistant Culex quinquefasciatus Larvae. Applied and Environmental Microbiology, 73 (19). Retrieved from http://www.ncbi.nlm.nih.gov/pmc/articles/ PMC2074985/ in October 15, 2012.

Wisotzjsey, J. D., Jurtshuk, P. J., Fox, G. E., Deinhard, G., \& Poralla, K. (1992). Comparative Sequence Analyses on the 16s $r$ RNA (rDNA) of Bacillus acidocaldarius, Bacillus acidoterrestris, and Bacillus cycloheptanicus and Proposal for Creation of a New Genus, Alicyclobacillus gen. nov. International Journal Of Systematic Bacteriology, 42 (2). Retrieved from http://www.ncbi.nlm.nih.gov/ pubmed/1374624 in October 23, 2012.

Wolfgang, S. R., \& Rolf, D. (2010). Metagenomics: Methods and protocols- Methods in Molecular Biology. New York: Humana Press. 